\title{
Spillovers in Regional Fisheries Management: \\ Do Catch Shares Cause Leakage?
}

\author{
Sam Cunningham ${ }^{1}$, Lori S. Bennear ${ }^{2}$, and Martin D. Smith ${ }^{3 *}$
}

1. Economist, North Pacific Fishery Management Council, Anchorage, 605 West 4th, Suite 306, Anchorage, AK 99501, Email: sam.cunningham@noaa.gov

2. Associate Professor of Environmental Economics and Policy, Nicholas School of the Environment, Department of Economics, and Sanford School of Public Policy, Duke University, Box 90328, Durham, NC 27708, Email: lori.bennear@duke.edu

3. Professor of Environmental Economics, Nicholas School of the Environment and Department of Economics, Duke University, Box 90328, Durham, NC 27708, Email: marsmith@duke.edu, ph: (919) 613-8028, fax: (919) 684-8071

* Corresponding author.

\section{Acknowledgements}

We thank Rich Seagraves and Jason Didden for helpful discussions and providing access to data; and for helpful comments on earlier versions of this work, we thank environmental economics and policy faculty and students in the Nicholas School of the Environment, conference participants at NAAFE 2013 in St. Petersburg, FL, conference participants at AERE 2013 in Banff, Canada, Don Fullerton, Kathy Baylis, two anonymous reviewers, and the editor. 


\title{
Spillovers in Regional Fisheries Management: \\ Do Catch Shares Cause Leakage?
}

\begin{abstract}
Regional councils manage United States fisheries. Fishermen can participate in fisheries managed by multiple councils, and effort controls in one region could lead to effort leakage into another. Theoretical modeling demonstrates that positive, negative, and no leakage are possible. Using difference-in-differences, we test for leakage across regional boundaries for a catch share program in New England and find evidence that the New England groundfish sector program caused spillover into adjacent Mid-Atlantic fisheries. Aggregate Mid-Atlantic harvest volume increased among sector members after the policy change. We find leakage in individual fisheries with similar gear and high market substitutability with sector species.
\end{abstract}

JEL Codes: Q22, Q28, H73

Keywords: catch shares, cooperatives, difference-in-difference, regional policies, interjurisdictional regulation 


\section{Introduction}

United States commercial fisheries conducted in federal waters are managed by regional fishery management councils that represent collections of states. An individual fishery's assignment to a particular management council generally reflects the species range, its proximity to the political boundaries of participating states, and home ports of participating fishermen. However, species ranges can span management borders and ultimately link together fishermen whose home ports are in different regions. The result is that individual fishermen can participate in multiple fisheries managed by different councils. This institutional arrangement raises the question of whether a policy change for a fishery in one region will affect outcomes for fisheries in other regions that were not directly involved in the policy process. Most policy evaluation focuses on the intended effect on the target fishery and fails to account for potential ancillary effects on other fisheries. In this paper, we test for the existence of policy-induced transboundary impacts on fishery outcomes and explore the implications for regional fisheries management. We examine whether a policy change in one region-from industry-wide quotas with effort restrictions to catch shares - affects adjacent fisheries in another region that are managed with industry-wide quotas.

An important motivation for our study is the trend toward using catch shares to manage fisheries in the United States and in many other parts of the world. Economists have focused their empirical attention on the economic and biological consequences of catch share programs for the target fisheries. Evidence for economic efficiency gains is strong-from fishery case studies, ex-ante empirical analyses, and individual fishing quota market data (Weninger 1998; NRC 1999; Grafton, Squires, and Fox 2000; Newell, Sanchirico and Kerr 2005; Lian, Singh, and Weninger 2009). There is still debate about whether catch shares improve biological outcomes in the target fishery, i.e. whether apparent gains reflect other policy measures or population changes 
are plausibly attributable to catch shares (Costello, Gaines, and Lynham 2008; Bromley 2009; Nowlis and van Benthem 2012). As this debate continues, economists are beginning to examine the effects of catch share programs on employment (Abbott, Garber-Yonts, and Wilen 2010) and the implications of distributional consequences for policy design (Pereau, Little, Doyen, and Thebaud 2012).

Although understanding the direct effects of catch share programs is important, evidence of fishery spillovers from a range of policy contexts suggests that indirect effects are likely to matter. One area of research examines how effort for "targeted" species affects catch of nontargeted species. Scholars have found that overall fishing effort supply reflects target fishery entry and exit decisions (Bockstael and Opaluch 1983) as well as finer-scale targeting decisions within multi-species fisheries (Zhang and Smith 2011). Effort also adjusts spatially to economic incentives on fine scales such as fishing grounds (Holland and Sutinen 2000; Smith 2002; Zhang and Smith 2011) and across large regions (Mistiaen and Strand 2000; Smith and Wilen 2004; Hicks and Schnier 2008). Other work examines how regulation of one target species or one fishing location changes the opportunity cost of fishing effort and thus affects outcomes for other species and locations. Quaas and Requate (2013) show theoretically that regulation of one species can lead to depletion of other stocks that otherwise would have been less depleted under open access. There is some evidence for this process occurring within regions in which Individual Fishing Quotas (IFQs) affect the targeting of unregulated species (Asche, Gordon, and Jensen 2007; Hutniczak 2014). Others find evidence of this process in the effects of regulation of a target species on a bycatch species (Abbott and Wilen 2011). At a global scale, the hypothesis of "roving bandits" suggests that excess fishing capacity roams the globe to exploit profit opportunities where local institutions have failed to restrict access (Berkes et al. 2006). The 
evidence for this phenomenon is less direct than the empirical studies in fishing behavior, but the mechanism is plausible. All of this work highlights the potential for a policy change in one region to affect fishery outcomes in another.

Outside of fisheries, economists have paid considerable attention to policy spillovers generally, and leakage specifically. For example, if one country imposes restrictions on carbon emissions (e.g., a carbon tax or cap-and-trade system), carbon-intensive industries have an incentive to relocate to countries without these restrictions. The overall reduction in carbon is lower because of this "leakage" (Goulder and Parry 2008, Wiener 2007, Fowlie 2009). Carbon policies can also create leakage through natural resource markets. Carbon sequestered in conserved forests in one location may be offset by carbon emissions from deforestation in other areas, and there is a substantial potential for leakage in the U.S. forest sector (Murray, McCarl, and Lee 2004). Indirect evidence from trade in forest products is also consistent with a leakage mechanism; reforestation gains in seven developing countries are mostly offset by land use changes in other countries (Meyfroidt, Rudel, and Lambin 2010). Recent theoretical work suggests the possibility of negative leakage if a carbon tax changes the production mix and draws more productive resources into the newly regulated sector from the unregulated sector (Baylis, Fullerton, and Karney 2014).

We examine the potential of leakage due to regional-specific fisheries regulation. Our empirical analysis examines the impacts of the 2010 New England Groundfish Sector Program (Sector Program hereafter) on adjacent fisheries in the Mid-Atlantic Region. Similar to how IFQs operate, the Sector Program allocates shares of groundfish total allowable catch (TACs) to cooperative entities called sectors. The economic logic is that these sectors will rationalize the deployment of fishing effort, lower costs, increase revenues through market timing, and profit 
share. The baseline policy prior to the Sector Program used effort controls (specifically nontransferable days-at-sea restrictions) to enforce the TAC. Recent work using quasi-experimental methods finds evidence of economic benefits of sector management on target fisheries (Scheld et al. 2012; Scheld and Anderson 2014), and survey-based research finds evidence that sector formation is correlated with social capital (Holland et al. 2013). However, empirical work on the Sector Program to date does not address the potential impacts on other fisheries. We hypothesize that regulation in one region (New England) frees up fishing capital to exploit fisheries in another region (the Mid-Atlantic) that have lower barriers to entry. In practical terms, many New England Groundfish vessels had permits and established catch records for Mid-Atlantic species before the Sector Program. This regulatory history coupled with species ranges that in some cases span both regions suggest that there were low barriers to entry; the Sector Program might have lowered the average opportunity cost of using capital from New England fisheries in adjacent Mid-Atlantic fisheries. On the other hand, increased profitability of New England fisheries could draw high-skill New England effort into New England fisheries and away from Mid-Atlantic fisheries. If low-skill New England effort operating in Mid-Atlantic fisheries does not have an incentive to increase fishing in the Mid-Atlantic, the net effect would be negative leakage. The central question of this paper is to what extent New England groundfish fisherman increased participation in the Mid-Atlantic as a result of groundfish sector management that altered the deployment of fishing effort in New England.

In the next section, we describe the fisheries and the regulatory systems before and after the policy change. This background motivates the development of a simple theoretical model in the following section. The model shows that no leakage, positive leakage, and negative leakage are all possibilities and hence, understanding the extent of leakage is an empirical question. We 
approach this empirical question by by analyzing the creation of the Sector Program as a natural experiment. The control group includes Mid-Atlantic fishermen who did not fish for New England groundfish (sector) species before the program. We use their fishing outcomes (catches and revenues) before and after the Sector Program to estimate our counterfactual. We use a difference-in-differences (DID) estimator to isolate the treatment effect. We estimate models with both pooled and disaggregated Mid-Atlantic species and perform falsification tests. We find evidence of positive leakage in the aggregate data, but the effects are heterogeneous across individual fisheries.

\section{Background}

The New England groundfish complex includes a diverse set of commercially caught demersal species. Historically, these fisheries were among the highest volume and value fisheries in the United States, with Atlantic cod (Gadus morhua) being the most notable species. Table 1 contains landings data for each groundfish species in 2009, the year prior to Sector Program implementation. Although all of these species are marketed as varieties of whitefish, speciesspecific ex-vessel price per pound ranges from $\$ 0.48$ to $\$ 1.66$. These prices reflect the continuum of market categories, including inputs into processed products like fish sticks, fillets for fish and chips, and higher-end plate fish. Nevertheless, compared to typical high-end whitefleshed plate fish such as red snapper, grouper, and halibut, the groundfish prices are low. For context, the 2009 red snapper ex-vessel price per pound averaged across all U.S. fisheries was $\$ 3.24$. Table 1 also breaks down landings by gear type. Otter trawl is the dominant gear type $(61 \%)$ with substantial catches from gillnets (34\%). The vast array of other fishing gear types account for only $5 \%$ of landings for which gear information is available. Across the fisheries, 
there is some variation in the shares of different gears. Most are heavily dominated by otter trawl, but gillnets contribute roughly half for cod and pollock.

A number of factors could facilitate spillover from New England sector (NES) to MidAtlantic (MA) fisheries. Home port states of NES fishermen ${ }^{1}$ include all of the New England states with marine coastlines but also include several states from the adjacent Mid-Atlantic Region. New Jersey, for instance, is listed as a home port for fishermen in seven of the sectors. Other Mid-Atlantic states in the list include New York, North Carolina, and Virginia. Beyond geography, there are possibilities of market substitutability, gear substitutability, and institutional barriers. Market substitutability would matter if fishermen have an easier time identifying buyers for products that are close market substitutes than for products that are qualitatively different. If a fisherman can use the same gear to catch a different species, then the fisherman does not need to incur the costs of changing gear and potentially learning a new fishing method. If the Sector Program indeed frees up capital, it frees up vessel time and the gear on that vessel. Lastly, institutional barriers could prevent spillovers by increasing the cost of entry. Our data do not allow us to explore the relevance of institutional barriers because Mid-Atlantic fisheries with qualitatively different regulatory institutions_-namely catch share-based management that would require entrants to purchase quota — also use very different types of gear from those used to catch New England groundfish.

Table 2 contains landings data for species managed by the Mid-Atlantic Fishery Management Council. Here, all species are included to consider all possibilities for leakage from New England into the adjacent region. There are four species that we categorize as whitefish: summer flounder, scup, black sea bass, and tilefish. Summer flounder plausibly competes with

\footnotetext{
${ }^{1}$ Throughout our paper, we use "fishermen" and "vessels" interchangeably. Licenses are tied to vessels. Many vessels are owner-operated by fishing captains, while some vessels have captains for hire.
} 
the flounder species in the New England groundfish complex (winter flounder, yellowtail flounder, and plaice) despite having a higher ex-vessel price. Scup similarly is a plausible market competitor for the lower end whitefish species in New England (hake, pollock, and redfish). The other two species, black sea bass and tilefish, are higher end plate fish, have ex-vessel prices that are substantially above those of the highest priced groundfish, and thus are less likely to compete with groundfish directly in the market.

The species categorized as Other Seafood in Table 2 are all qualitatively different from groundfish. Monkfish, though white fleshed, is a unique product; its tale is consumed and is textured like lobster. Atlantic mackerel is a low-end, oily pelagic fish with an ex-vessel price per pound that is less than half of the lowest priced groundfish species. Butterfish is a small, bony fish that was once marketed to Asia but now has no direct target fishery and is caught as bycatch. Long-finned squid, surfclam, and ocean quahog produce very different seafood products from whitefish. Bluefish is a low-end oily fish that spoils easily and thus does not compete directly with groundfish, and spiny dogfish is a small shark that is often smoked. Despite all of these differences, participants in the sector program that substitute into MA species needed to have some established catch records for those species and, in the process, may have developed relationships with buyers. Considering market substitutability overall, spillovers are most likely for scup and summer flounder but cannot be ruled out for any of the MA species.

Analyzing MA landings by gear reinforces some of the market relationships but offers some other possible substitutes. Both summer flounder and scup are caught primarily by otter trawl, which is the dominant gear type for groundfish. As such, these species appear even more likely as spillover candidates. Black sea bass and golden tilefish are caught primarily by other gears (pots for bass and long line for tilefish). Combined with their market differentiation, 
spillovers for these species seem very unlikely. The same is true for surfclam and ocean quahog, which are caught with hydraulic dredges. In contrast, Atlantic mackerel, butterfish, and longfinned squid are all dominated by otter trawl, making these species strong candidates for spillovers for groundfish fishermen using otter trawls. Monkfish is a reasonable candidate on the basis of gear, with a substantial percentage of otter trawl but a higher percentage of gillnets. Spiny dogfish seems less likely with only a quarter landings coming from otter trawl. Bluefish is dominated by gillnet gear, so the likelihood of spillover hinges on whether gillnet groundfish fishermen are likely to spillover. Overall, given the dominance of otter trawl in groundfish, the best candidates for spillover on the basis of gear are summer flounder, Atlantic mackerel, butterfish, and long-finned squid, and secondary candidates include monkfish and scup.

The baseline regulatory environment prior to the formation of the Sector Program was regulated restricted access and fleet-wide quotas for both New England Sector (NES) and MidAtlantic (MA) fisheries. Each fishery required a permit to participate, the numbers of permits were limited, and, like most U.S. federally managed fisheries, TACs for the fleet as a whole were set on the basis of biological stock assessments. In NES fisheries, days-at-sea (DAS) restrictions limited the amount of effort to prevent the fleet from exceeding the TACs. MA fisheries, in contrast, relied on season closures to enforce TACs; as in regulated open access (Homans and Wilen 1997), MA fisheries are shut down when they reach the TACs. ${ }^{2}$

After the Sector Program, MA fisheries continued to be managed in the same way, whereas NES fisheries kept some of the baseline regulations and changed others. In particular,

\footnotetext{
${ }^{2}$ Two MA fisheries - ocean quahog and Atlantic surf clam-have individual fishing quotas (IFQs) as the management regime. Golden tilefish is transitioning to IFQ-based management, and the bulk of the TAC is caught by a small co-op (Kitts, Pinto da Silva, and Rountree 2007). In principle, a fisherman could purchase IFQ to enter these fisheries, but in practice this is likely a more substantial barrier to entry than for non-IFQ species. On the basis of institutional barriers, spillovers would seem less likely for surfclams, ocean quahog, and golden tilefish. Note that these species are also caught with different gear from that used to catch New England groundfish and yield qualitatively different products. So, we have no ability to distinguish empirically between gear, product substitutability, and institutional barriers and we ultimately exclude these species from the analysis.
} 
the biologically based TACs and limited entry programs were maintained for NES fisheries, but DAS restrictions were eliminated for Sector Program participants. Instead of DAS restrictions, shares of each TAC were allocated to cooperatives called sectors; the allocation to each sector was proportional to the combined historical catches of the fishermen that joined the sector. Sectors could then coordinate fishing effort in order to maximize profits. The presumption was that sectors could catch the same amount of fish using less effort and at lower cost than under the DAS restrictions. For more details on the regulatory history of NES fisheries, see Holland andWiersma (2010) and Cunningham (2012).

\section{Theoretical Model}

Our general hypothesis is that sector management, by promoting the efficient use of capital, frees up capital to target species in non-sector fisheries, including ones in the MidAtlantic Region. To examine sharper predictions about causal effects of the Sector Program, we develop a simple theoretical model. In the model, there are five fishermen, each representing a segment of the composite fleet that fishes for Mid-Atlantic (MA) and for New England sector (NES) species. All NES fishermen in the model are assumed to have permits to fish in MA fisheries, but MA fishermen only have permits for MA fisheries (our empirical specification below restricts the data set accordingly). These segments (and corresponding nomenclature for fishing effort) are: MA fishermen fishing only for MA species $\left(E^{M M}\right)$, low-type NES fishermen fishing for MA species ( $E^{L M}$ ), high-type NES fishermen fishing for MA species $\left(E^{H M}\right)$, low- 
type NES fishermen fishing for NES species $\left(E^{L S}\right)$, and high-type NES fishermen fishing for NES species $\left(E^{H S}\right)$. High (low) type indicates relatively high (low) fishing skill. ${ }^{3}$

Fishing effort is a composite of amount of gear deployed, fish-hold capacities of the vessels, time to find and catch fish, and time to identify a buyer when the fish are landed. In the latter sense, the model incorporates market substitutability on the input side. We assume that there are no output-side market considerations such that fishermen are price takers (discussed further below). To keep the model simple, we assume that fishermen who are high (low) type in sectors are also high (low) in the Mid-Atlantic. The corresponding harvest functions are: $H_{t}^{M M}\left(E_{t}^{M M}, X_{t}^{M}\right), H_{t}^{L M}\left(E_{t}^{L M}, X_{t}^{M}\right), H_{t}^{H M}\left(E_{t}^{H M}, X_{t}^{M}\right), H_{t}^{L S}\left(E_{t}^{L S}, X_{t}^{S}\right)$, and $H_{t}^{H S}\left(E_{t}^{H S}, X_{t}^{S}\right)$ where $t$ denotes time, $X_{t}^{M}$ is the stock of Mid-Atlantic species, and $X_{t}^{S}$ is the stock of sector species. We assume that the production functions capture fishermen heterogeneity and that all fishermen face a constant marginal cost of effort, $c$.

Because all species in both regions were managed with fleet-wide TACs before and after the policy change, and these TACs were determined by biological science alone, we assume that the sector program did not have any effects on biological stocks. ${ }^{4}$ This allows us to suppress the stock argument from each production function. We assume all production functions are strictly concave and that, for any arbitrary level of effort, marginal product of the high-type is higher than that of the low-type. Also because of tight biological controls, we suppress the time subscript $t$ in the modeling below and only distinguish between the periods before and after the policy change (denoted by before and after subscripts where necessary). We further assume that prices of Mid-Atlantic $\left(P^{M}\right)$ and sector species $\left(P^{S}\right)$ are exogenous and unchanged by the

\footnotetext{
${ }^{3}$ High and low type could also be thought of as high and low technical efficiency. In our simple theoretical model, technical efficiency is interchangeable with fishing skill.

${ }^{4}$ In U.S. federal fisheries management, management councils often set TAC at the same level for multiple years.
} 
policy. The rationale again flows from tight biological control; the policy change does not affect the total landed quantity of each species as long as catch limits bind both before and after (a reasonable approximation for nearly all MA and NES sector species, though our model can accommodate non-binding quotas). Even in the absence of binding catch limits, exogenous price may be a reasonable assumption given that the most of the species in our empirical work below compete in a global whitefish market and constitute a tiny fraction of that market. General equilibrium bioeconomic models of seafood markets, e.g. Quaas and Requate (2013), are more relevant for open access or management settings in which there are no binding biological controls on catches. ${ }^{5}$

Let $Q^{M}$ and $Q^{S}$ denote the TAC for, respectively, MA and NES species. The TACs are assumed to be the same before and after the policy change. The TAC constraints can thus be written as:

$$
H^{M M}\left(E^{M M}\right)+H^{L M}\left(E^{L M}\right)+H^{H M}\left(E^{H M}\right) \leq Q^{M}
$$

and

$$
H^{L S}\left(E^{L S}\right)+H^{H S}\left(E^{H S}\right) \leq Q^{S} .
$$

Denote the fishermen-specific shadow values (Mid-Atlantic, low-type, high-type) for [1] as $\gamma^{M M}, \gamma^{L M}$, and $\gamma^{H M}$. Similarly, denote the fishermen-specific shadow values (low-type, hightype) for [2] as $\gamma^{L S}$ and $\gamma^{H S}$. All fishermen have constraints on the maximum amount of effort that they can exert in a season: $\bar{E}^{M}, \bar{E}^{L}$, and $\bar{E}^{H}$. MA fishermen only exert effort in the Mid-

\footnotetext{
${ }^{5}$ Another possibility for price effects that we assume away is that sector program would alter the timing of catches, avoid market gluts, and thus increase prices as suggested by Homans and Wilen (2005). The iconic motivating example in Homans and Wilen (2005) is the Alaskan Pacific halibut case for which the race to fish collapsed the annual season length to just a few days. The transition to catch shares grew the season to over 240 days within a year. However, the dramatic derby conditions of Pacific halibut did not exist in New England prior to sector formation, and we can more reasonably assume no price effects from spreading the harvest.
} 
Atlantic, whereas NES fishermen exert effort in both NES and MA fisheries. The constraints with corresponding shadow values in square brackets are:

$$
\begin{array}{lc}
E^{M M} \leq \bar{E}^{M} & {\left[\mu^{M}\right]} \\
E^{L M}+E^{L S} \leq \bar{E}^{L} & {\left[\mu^{L}\right]} \\
E^{H M}+E^{H S} \leq \bar{E}^{H} & {\left[\mu^{H}\right]}
\end{array}
$$

These constraints reflect a combination of time available for fishing and finding buyers, sizes of vessels, and available gear. Prior to the policy change to sectors, there were also days-at-sea regulations that limited the amount of effort sector fishermen could apply to sector species. The limit is the same for both high and low types, $\bar{E}^{D A S}$, leading to the following constraints with corresponding shadow values in square brackets:

$$
\begin{array}{ll}
E^{L S} \leq \bar{E}^{D A S} & {\left[\mu^{L D}\right]} \\
E^{H S} \leq \bar{E}^{D A S} & {\left[\mu^{H D}\right]}
\end{array}
$$

All ten shadow values are strictly non-negative. We assume that for all sector fishermen, days-atsea limits are below their total effort capacities, $\bar{E}^{D A S} \leq \bar{E}^{L}$ and $\bar{E}^{D A S} \leq \bar{E}^{H}$.

We assume that the MA fishermen take NES fishermen effort in the MA fisheries as given. As such, their optimization problem has the same structure before and after the policy change; the only difference is how much NES fishermen are fishing in the Mid-Atlantic. Maximizing profits subject to constraints [1] and [3] yields the following Kuhn-Tucker conditions for MA fishermen:

$$
P^{M} \frac{\partial H^{M M}}{\partial E^{M M}}-c \leq \mu^{M}+\gamma^{M M} \frac{\partial H^{M M}}{\partial E^{M M}}
$$




$$
\begin{aligned}
& \gamma^{M M} \geq 0, \gamma^{M M}\left(H^{M M}\left(E^{M M}\right)+H^{L M}\left(E^{L M}\right)+H^{H M}\left(E^{H M}\right)-Q^{M}\right)=0, \mu^{M} \geq 0, \text { and } \\
& \mu^{M}\left(E^{M M}-\bar{E}^{M}\right)=0 .
\end{aligned}
$$

Maximizing profits for low-type NES fishermen subject to constraints [1], [2], [4], and [6] yields two sets of Kuhn-Tucker conditions both before and after the policy change. Before the policy change, they are:

$$
\begin{aligned}
& P^{M} \frac{\partial H^{L M}}{\partial E^{L M}}-c \leq \mu^{L}+\gamma^{L M} \frac{\partial H^{L M}}{\partial E^{L M}}, \\
& \gamma^{L M} \geq 0, \gamma^{L M}\left(H^{M M}\left(E^{M M}\right)+H^{L M}\left(E^{L M}\right)+H^{H M}\left(E^{H M}\right)-Q^{M}\right)=0, \mu^{L} \geq 0, \text { and } \\
& \mu^{L}\left(E^{L M}+E^{L S}-\bar{E}^{L}\right)=0 . \\
& P^{S} \frac{\partial H^{L S}}{\partial E^{L S}}-c \leq \mu^{L}+\mu^{L D}+\gamma^{L S} \frac{\partial H^{L S}}{\partial E^{L S}}, \\
& \gamma^{L S} \geq 0, \gamma^{L S}\left(H^{L S}\left(E^{L S}\right)+H^{H S}\left(E^{H S}\right)-Q^{S}\right)=0, \mu^{L D} \geq 0, \text { and } \mu^{L D}\left(E^{L S}-\bar{E}^{D A S}\right)=0 .
\end{aligned}
$$

For high-type fishermen whose constraints are [1], [2], [5], and [7] before the policy change, the Kuhn-Tucker conditions are:

$$
\begin{aligned}
& P^{M} \frac{\partial H^{H M}}{\partial E^{H M}}-c \leq \mu^{H}+\gamma^{H M} \frac{\partial H^{H M}}{\partial E^{H M}}, \\
& \gamma^{H M} \geq 0, \gamma^{H M}\left(H^{M M}\left(E^{M M}\right)+H^{L M}\left(E^{L M}\right)+H^{H M}\left(E^{H M}\right)-Q^{M}\right)=0, \mu^{H} \geq 0, \\
& \mu^{H}\left(E^{H M}+E^{H S}-\bar{E}^{H}\right)=0 . \\
& P^{S} \frac{\partial H^{H S}}{\partial E^{H S}}-c \leq \mu^{H}+\mu^{H D}+\gamma^{H S} \frac{\partial H^{H S}}{\partial E^{H S}}, \\
& \gamma^{H S} \geq 0, \gamma^{H S}\left(H^{L S}\left(E^{L S}\right)+H^{H S}\left(E^{H S}\right)-Q^{S}\right)=0, \mu^{H D} \geq 0, \text { and } \mu^{H D}\left(E^{H S}-\bar{E}^{D A S}\right)=0 .
\end{aligned}
$$


After formation of sectors, individual fishing quotas are assigned to low- and high-type fishermen that add up to the TAC:

$\bar{q}^{L}+\bar{q}^{H}=Q^{S}$

This policy change brings into alignment the shadow value of individual NES fishermen for the NES species, which we denote as $\lambda$ to distinguish it from the period before the policy change. In equilibrium, $\lambda$ is also the quota price in each fisherman's optimization. After the policy change, there are no longer days-at-sea restrictions on participants in the Sector Program, so constraints [6] and [7] disappear. The Kuhn-Tucker conditions for the MA fisheries are unchanged for both MA and for NES fishermen, but the shadow values themselves can be influenced. For low-type NES fishermen after the policy change, the Kuhn-Tucker conditions for MA fisheries are the same, and for NES fisheries they are:

$$
\begin{aligned}
& P^{S} \frac{\partial H^{L S}}{\partial E^{L S}}-c \leq \mu^{L}+\lambda \frac{\partial H^{L S}}{\partial E^{L S}}, \\
& \lambda \geq 0, \lambda\left(H^{L S}\left(E^{L S}\right)+H^{H S}\left(E^{H S}\right)-Q^{S}\right)=0, \mu^{L} \geq 0, \text { and } \mu^{L}\left(E^{L S}+E^{L M}-\bar{E}^{L}\right)=0 .
\end{aligned}
$$

For high-type NES fishermen after the policy change, the Kuhn-Tucker conditions for the MA fisheries are the same, and for NES fisheries they are:

$$
\begin{aligned}
& P^{S} \frac{\partial H^{H S}}{\partial E^{H S}}-c \leq \mu^{H}+\lambda \frac{\partial H^{H S}}{\partial E^{H S}} \\
& \lambda \geq 0, \lambda\left(H^{L S}\left(E^{L S}\right)+H^{H S}\left(E^{H S}\right)-Q^{S}\right)=0, \mu^{H} \geq 0, \text { and } \mu^{H}\left(E^{H S}+E^{H M}-\bar{E}^{H}\right)=0 .
\end{aligned}
$$

Proposition 1: If no constraints bind, the policy change has no effect on effort and produces no effort leakage. 
Proof: When no constraints bind, the shadow values are all zero. Because the aggregate NES quota does not bind, $\lambda=0$. As a consequence, each fisherman equates the value of marginal product in each fishery to the marginal cost of fishing effort. Conditions describing optimal behavior of MA fishermen are identical before and after the policy change. For NES fishermen, the condition in [12] is identical to the one in [19], and the condition in [16] is identical to the one in [21]. Thus, all solutions are interior and identical before and after the policy change.

Proposition 1 may not represent the most interesting case, but it is a realistic possibility. In two adjacent fisheries managed by regulated restricted access, it is theoretically possible that the restrictions on number of entrants are sufficiently tight that there is not enough total effort available to catch the entire quota in each fishery profitably. In essence, every fisherman is behaving as a competitive firm equating marginal revenue to marginal cost before and after the policy change, the fleets do not catch all of the quota, so the change has no effect. Of course, Proposition 1 also requires that DAS constraints are sufficiently high that no fishermen could increase profits by loosening them.

Because there are so many constraints, the model described above presents numerous other possible qualitative outcomes, and we examine only a subset. To explore sharp predictions from these cases requires additional assumptions. For Proposition 2 below we make three assumptions: A2.1) the overall NES quota constraint is binding before and after the policy change ([2] holds with equality); A2.2) DAS constraints are binding for low- and high-type NES fishermen before the policy change ([6] and [7] hold with equality); and A2.3) effort constraints 
are binding before and after the policy change for both high- and low-type NES fishermen ([4] and [5] hold with equality).

Proposition 2: The formation of sectors can induce positive leakage of NES fisheries effort into MA fisheries.

Proof: Because days-at-sea constraints bind, i.e. $E_{\text {Before }}^{L S}=E_{\text {Before }}^{H S}=\bar{E}^{D A S}$, $E_{\text {Before }}^{L M}=\bar{E}^{L}-\bar{E}^{D A S}$ and $E_{\text {Before }}^{H M}=\bar{E}^{H}-\bar{E}^{D A S}$. Because $H^{L S}\left(\bar{E}^{D A S}\right)+H^{H S}\left(\bar{E}^{D A S}\right)=Q^{S}$, A2.1, and by assumption $\frac{\partial H^{H S}(\bar{E})}{\partial E}>\frac{\partial H^{L S}(\bar{E})}{\partial E}, E_{\text {After }}^{L S}<E_{\text {Before }}^{L S}$ and $E_{\text {After }}^{H S}>E_{\text {Before }}^{H S}$. These conditions imply $E_{\text {After }}^{L M}>E_{\text {Before }}^{L M}$ and $E_{\text {After }}^{H M}<E_{\text {Before }}^{H M}$. Again, because

$$
\begin{aligned}
& \frac{\partial H^{H S}\left(\bar{E}^{D A S}\right)}{\partial E}>\frac{\partial H^{L S}\left(\bar{E}^{D A S}\right)}{\partial E},\left(E_{\text {Affer }}^{H S}-E_{\text {Before }}^{H S}\right)<\left(E_{\text {Before }}^{L S}-E_{\text {After }}^{L S}\right) . \text { Because of A2.3, } \\
& \left(E_{\text {After }}^{H M}-E_{\text {Before }}^{H M}\right)<\left(E_{\text {Before }}^{L M}-E_{\text {Affer }}^{L M}\right) .
\end{aligned}
$$

When Proposition 2 holds, whether the net increase in NES fisherman effort in MA fisheries translates into increased catches for NES fishermen depends on the production functions; the increased low-type NES effort in MA fisheries and associated increased catches could be more, less, or exactly equal to catch decreases from shifting high-type effort away from MA fisheries. If low- and high-type NES fishermen were equally productive in MA fisheries, of course, the prediction would be an increase in NES catches of MA fish. If low-type NES fishermen are also low-type in MA fisheries, Proposition 2 holds (positive effort leakage), and MA catches are unchanged, NES catches of MA species would also be unchanged because of binding TACs. 
This result would translate into a drop in technical efficiency in MA fisheries; the low-type NES effort increased, and the high-type NES effort decreased. ${ }^{6}$

Now consider modifying one of the assumptions above and addition an additional assumption to derive the opposite conclusion from Proposition 2. For Proposition 3, we keep A2.1 as A3.1 and A2.2 as A3.2, but we replace A2.3 with A3.3) effort constraints are binding before and after the policy change for high-type NES fishermen ([5] holds with equality), but the effort constraint is not binding before the policy change for low-type NES fishermen. In addition, we assume A3.4) the MA quota constraint is not binding before the policy change for low-type NES fishermen. This assumption could reflect either of two cases: 1) when the MA quota does not bind in general or 2) when low-type NES fishermen reach their profit maximizing effort level before the MA quota binds. In both cases, the MA quota constraint shadow value is zero for NES low-type fishermen.

Proposition 3: The formation of sectors can induce negative leakage of NES fisheries effort into the MA fisheries.

Proof: Because days-at-sea constraints bind, i.e. $E_{\text {Before }}^{L S}=E_{\text {Before }}^{H S}=\bar{E}^{D A S}$, $E_{\text {Before }}^{L M}<\bar{E}^{L}-\bar{E}^{D A S}$ and $E_{\text {Before }}^{H M}=\bar{E}^{H}-\bar{E}^{D A S}$. Because $H^{L S}\left(\bar{E}^{D A S}\right)+H^{H S}\left(\bar{E}^{D A S}\right)=Q^{S}$, A3.1, and by assumption $\frac{\partial H^{H S}(\bar{E})}{\partial E}>\frac{\partial H^{L S}(\bar{E})}{\partial E}, E_{\text {After }}^{L S}<E_{\text {Before }}^{L S}$ and $E_{\text {After }}^{H S}>E_{\text {Before }}^{H S}$. These conditions implies $E_{\text {After }}^{H M}<E_{\text {Before }}^{H M}$; high-type effort decreases in MA fisheries. However, because low-type effort is not binding and the MA quota constraint does not bind for

\footnotetext{
${ }^{6}$ Another possibility, as suggested by a reviewer, is that the NES effort leakage displaces MA effort in MA fisheries when there is positive effort leakage and a positive effect on NES catches. This could actually increase technical efficiency in MA fisheries.
} 
low-type fishermen, $P_{M} \frac{\partial H^{L M}}{\partial E^{L M}}-c=0$; low-type effort in MA fisheries was already at an interior solution before the policy change, so there is no incentive to increase effort after the policy change. Thus, $E_{\text {After }}^{L M}=E_{\text {Before }}^{L M}$, and $\left(E_{\text {After }}^{H M}-E_{\text {Before }}^{H M}\right)+\left(E_{\text {After }}^{L M}-E_{\text {Before }}^{L M}\right)=\left(E_{\text {After }}^{H M}-E_{\text {Before }}^{H M}\right)<0$.

If A3.4 does not hold, negative leakage may still be possible, but it depends on the magnitudes of changes: how much high-type NES effort leaves MA fisheries, how much that influences the MA quota shadow value, and how much, in turn, that increases low-type NES effort in MA fisheries and offsets some (or all) of the high-type NES effort moving to NES fisheries. Because the focus of Proposition 3 is to show that negative leakage is possible to motivate the empirical analysis, exploring these other conditions under which it could occur is beyond our scope.

In the case of negative leakage, the rationalization of effort in NES fisheries has a spillover rationalization effect in MA fisheries. Although MA fisheries remain regulated restricted access after the policy change in New England, some capital has effectively been removed from MA fisheries. This consequence echoes the mechanism that gives rise to negative leakage in Baylis, Fullerton, and Karney (2014), namely movement of more productive resources toward the newly regulated sector. In our case, these more productive resources would be the high-type NES fishing effort. Whether that effort removed is excess effort or whether the MA fisheries after the policy are underutilized would be yet another empirical question.

Overall, our three propositions highlight that the question is ultimately empirical. Even with a simple theoretical model developed above, it is not possible to have a priori predictions about leakage without knowing which constraints bind. The regulatory history suggests that DAS 
restrictions were definitely binding before the policy change, and TACs in both regions for nearly all of the managed fisheries were also binding. These stylized facts suggest Proposition 1 is not relevant to the empirical setting, but either Propositions 2 or 3 could be relevant. Whether effort constraints under the restricted access programs in MA and NES fisheries were binding is unclear.

\section{Data and Methods}

We are interested in testing for a causal relationship between the expansion of New England's groundfish sector management program and altered levels of participation in Mid-Atlantic commercial fisheries. To this end, we employ a difference-in-differences estimator that relies on defining treatment and control groups and measuring outcomes before and after the policy change. In this case, treatment groups are collections of the individual fishermen who may or may not have altered their level of fishing behavior in Mid-Atlantic fisheries after the implementation of NEFMC Northeast Multispecies FMP Amendment 16 on May 1, 2010. These are the NES fishermen fishing for MA species in the theoretical model. For statistical comparison, control groups are defined to include the individual fishermen who participated in Mid-Atlantic fisheries during the same study years, but were not affected by policy change in New England (from the theoretical model, MA fishermen fishing for MA species). The empirical model estimates the level of a measured outcome for the average individual fishermen, so implicitly we average over low-type and high-type NES fishermen.

Although the ideal outcome of interest is fishing effort, we lack a direct measure of effort and instead use two alternative outcome variables: landed volume and revenue. For these variables, National Marine Fisheries Service (NMFS) collects complete data from both 
fishermen and fish-dealers, so the commercial fisheries database contains some cross checks. For this study, we have access to this database, which includes every individual fishing vessel's landed quantity and gross revenue by species for every day from January 1, 2006 through November 30, 2011. Data on raw landings by individual vessel permits were reshaped to form a balanced panel around the sharp Sector Program implementation date of May 1, 2010.

Treatment groups are defined to include those individual fishermen whom one might expect to be changing their Mid-Atlantic fishery participation in response to the expansion of groundfish sectors. We consider three different formulations of treatment:

Group 1: All fishermen with landings of MA species who also reported landing any species managed under the New England Northeast Multispecies (groundfish) FMP, between 2006-2011;

Group 2: All Group 1 fishermen who are enrolled in one of the 17 New England groundfish sectors;

Group 3: All Group 2 fishermen who are enrolled in one of the 17 New England groundfish sectors, but who are reported by their sector manager as "inactive" in that year's Sector Operations Plan submitted for NMFS approval prior to the May 1 start of the fishing year.

Group 1 provides the broadest definition of treatment. Group 2 is a subset of Group 1, and Group 3 is a subset of Group 2. Running a model with the Group 1 treatment definition would indicate the effect of the Sector Program if any, on the level of MA fishery participation for any individual whose landings history links him or her to the New England groundfish fishery. Using treatment Group 1 takes a wide view of who comprises the potential source of leaked effort. Finding a significant difference-in-differences estimator for a Group 1 model run 
could be taken to indicate a watershed change in how the fishing population targets NES and MA species as a result of the Sector Program.

Group 2 fishermen are a subset of Group 1; Group 2 includes only those individuals who enrolled in a sector, thereby contributing their catch history to the sector's collectively managed allocation. Total enrollment across 17 sectors in 2011 was 819 individuals. In keeping with the idea that sector management creates opportunities to expand fishing activity beyond New England groundfish - by virtue of increased flexibility to catch groundfish over the entirety of the fishing season - one would expect to see a stronger positive increase in Mid-Atlantic fishery participation in Group 2 models relative to Group 1 models. If difference-in-differences estimates are significant for Group 2 but not for Group 1, one could infer that the Sector Program altered MA fishing effort for participating individuals, but not the entirety of the fishing community that lands NES species.

Group 3 fishermen are a subset of Group 2, including those individuals who reap the financial benefits of their sector's collective catch but do not actively fish their own allocated share. The number of inactive sector members was 448 in 2011. Idled in New England fisheries by their sector managers, inactive sector members might have the greatest opportunity to redirect effort into MA fisheries. Some of these fishermen may have been idled because their vessels are less efficient or because they had a lesser desire to continue fishing. This possibility cuts against the likelihood of a positive treatment effect. Nevertheless, holding fishing skill and vessel efficiency constant, treatment Group 3 should show the strongest, most positive increase in MidAtlantic fishery participation. That said, the many ways that substitution can unfold leads to some ambiguity in predictions, and the lack of a single definitive theoretical basis for defining treatment is another reason to consider multiple definitions of treatment. 
In an ideal experiment, treatment and control groups would be the same in every way except for their levels in the outcome variable of interest. In such a case, the difference in the mean outcome level between the treatment and control groups would provide a confident measure of the effect of being in the treatment group. The multitude of unobservable factors affecting pounds and value of landings make it impossible to control for every factor that explains the difference in outcome levels between treatment and control. Weather, local product demand, and the strength of the overall economy as it impacts the opportunity cost of a fisherman's time are just a few examples of these unobservable factors that are not reported in commercial fisheries data. Difference-in-differences estimation is an appropriate strategy for this case because it compares the relationship between trends in outcome levels over time for treatment and control groups. The identifying assumption of this strategy is that, in the absence of treatment, the difference in the treatment and control groups' outcome levels - explained by omitted unobserved factors - remains the same over time. This first-stage difference describes the relationship between the underlying trends in treatment and control group fishing effort prior to policy implementation.

We use an ordinary least squares (OLS) regression-based difference-in-differences estimator with fixed-effects. A regression model is superior to the mean differencing estimation in its ability to control for variation in outcomes that are attributable to time period effects that are independent of the observational unit and time-independent effects. Effects that are invariant across time periods would include the essential differences between fishermen, such as relative access to capital, skill level, relationships with buyers, or experience. Fixed-effects models provide valid estimates of outcomes even if the unobserved, time-independent individual effects are correlated with other regressors. As with other OLS models, conditional exogeneity is 
required. This means that, after controlling for observable and unobserved factors that differentiate one individual in the sample from another, the expected value of the residual error is zero (Hayashi 2000, p.7).

Each calendar year was subdivided into three seasonal periods, or trimesters (JanuaryApril; May-August; September-December), creating 18 time periods within the time series. Including a dummy variable as a regressor for each portion of the year absorbs the effect of timespecific aggregate landings shocks that would be correlated across individuals in a certain period, regardless of the year. Controlling for seasonal variation is particularly important when analyzing fisheries because harvest patterns vary significantly in response to stock movements, spawning seasons, weather, regulatory restrictions, market conditions, and intense derby periods in regulated open access fisheries. A vector of year dummy variables is also included to control for variation in outcomes that are unique to a given year but affect all individuals equally. Including year and seasonal effects in a fixed-effects model effectively yields individual-specific time trends. We also include a linear time trend for the trimester-year combination. This time trend absorbs any monotonic changes in catch or value over the entire time period. ${ }^{7}$ The fixed effects difference-in-differences models used are of the form:

$Y_{i p y}=\beta D_{i p y}+\theta T_{p y}+\gamma_{p}+\delta_{y}+\alpha_{i}+\varepsilon_{i p y}$

Where $i$ denotes an individual fisherman, $p$ denotes a time period within the year, $y$ denotes a year, $Y_{i p y}$ is the outcome level for individual $i$ in time period $p$ and year $y, \mathrm{D}_{\text {ipy }}$ takes the value of 1 for treated individuals in time period $p$ and year $y$ and 0 for control, $T_{p y}$ is a linear time trend for the period-year combination, $\gamma_{p}$ are time period dummies, $\delta_{y}$ are year dummies, $\alpha_{i}$ are individual fixed-effects and $\varepsilon_{i p y}$ is the error term which is assumed to be independent across

\footnotetext{
${ }^{7}$ We cannot include period-year dummy variables as they would be perfectly collinear with the treatment variable.
} 
different fishermen, but allowed to be correlated for different period observations for the same fisherman. The estimated value of $\beta$ is interpreted as the differences-in-differences estimator. The models were run with both POUNDS ipy $_{V A L U E_{i p y}}$ as the dependent variable.

The critical identifying assumption in a difference-in-differences model is that in the absence of treatment, trends in outcomes between the treated and control groups would have been parallel. To test the validity of this identifying assumption, we conduct falsification tests for all outcomes that have statistically significant treatment effects. To do this we drop all posttreatment data (years 2010 and beyond) and redefine 2008 as the proxy "treatment" year. Thus, data from 2006 and 2007 are considered "pre-treatment" and data from 2008 and 2009 are considered "post-treatment." The exact same difference-in-differences models are run on these data. Since there was actually no treatment during this entire period, if the identifying assumption holds, we should observe no statistically significant treatment effect.

Defining the scope of "Mid-Atlantic fisheries" is critical to conducting policy-relevant model runs. The MAFMC directly manages 13 marine species under seven FMPs. Twelve of these species are listed in Table 2, and the last is short-finned squid, which does not appear in the aggregate NMFS database for landings by gear (so was excluded from the table). Short-finned squid landings do appear in our micro-level database and can be used in the analysis. The broadest possible definition of Mid-Atlantic fisheries thus includes all 13 species. We pare down the full roster of Mid-Atlantic species to eight highly-susceptible species based on the following reasoning. New England groundfish species are primarily targeted with bottom and mid-water trawl gear. Landings data on surfclams and ocean quahogs were excluded given the specialized nature of the shellfish dredging fishery, the very different product (not substitutable for whitefish characteristic of New England groundfish), and the fact that they are managed with catch shares. 
Tilefish data were excluded due to the small number of active fishermen, gear differences, and low entry pressure that has created a de facto ITQ fishery. Bluefish data were excluded because the fishery is low-value and is mainly prosecuted with hook-and-line gear. Black sea bass data were excluded because over $40 \%$ of landings are taken with pot fishing gear, and commercial landings are heavily outweighed by recreational fishing (NOAA 2012). Using each of the three treatment groups in turn, the model was run to determine effects on aggregated pounds and landed value outcomes for the eight remaining species: summer flounder, scup, spiny dogfish, long-finned squid, short-finned squid, Atlantic mackerel, butterfish, and monkfish. These models provide a region-wide look at altered activity patterns in the Mid-Atlantic. This highsusceptibility aggregate-level analysis is the main test of our hypothesis that the Sector Program induced spillover into the Mid-Atlantic.

We also consider model runs for individual species or combinations of species. We base these runs on identifying likely candidates for spillovers. The number of individual fishermen included in a single model run is always large, with a minimum of 519 and a maximum of 2,380. As discussed above, the appeal of fishing for Mid-Atlantic species to New England fishermen could stem from geographical stock distributions that straddle management regions, the amount of overlap in fishing seasons, ease of permit access for Mid-Atlantic species, similarity of the product market, or the similarity between the type of gear used on New England groundfish and identified Mid-Atlantic species. In addition to using information in Tables 1 and 3, these attributes were assessed based on information available from NMFS and Northeast Fisheries Science Center (NEFSC) (NOAA 2012, NEFSC 2006) as well as personal communication with MAFMC staff (Seagraves 2012). 
Noting that susceptibility to redirected effort varies across species according to the factors mentioned above, the three-treatment approach was applied to landings data for each of six Mid-Atlantic species in isolation. The model runs used data on summer flounder, scup, longfinned squid, Atlantic mackerel, butterfish and monkfish. Spiny dogfish and short-finned squid were dropped, having been identified as primarily incidental bycatch species, and we combined summer flounder and scup to create a single whitefish category. Table 3 summarizes the total number of fishermen targeting different groups of Mid-Atlantic species and how many vessels are in treatment and control groups. Across models, the control group remains unchanged. This group corresponds to Mid-Atlantic fishermen who never (in sample) have landed any of the sector species. Moving from Treatment Group 1 (all vessels with catch records of sector species) to Treatment Group 2 (enrolled sector members) raises questions about whether some of the what we count in Treatment Group 1 and exclude from the control group are, in fact, MidAtlantic fishermen who have had some incidental landings of sector species. In other words, we can be confident that all fishing vessels in Treatment Groups 2 and 3 are treated with the Sector Program, but it is possible that some fishermen in Treatment Group 1 should actually be in the control group. By excluding these fishermen altogether in model runs with Treatment Groups 2 and 3, we believe that our experimental design errs on the side of being conservative.

\section{Results}

We estimate models for each of the three treatment group definitions (3 groups), both pounds landed and dollar value (2 groups), and all eight vulnerable species plus five individual species or combinations of species (6 groups) for a total of 36 models $(3 \times 2 \times 6)$. All statistical significance is based on standard errors that are clustered at the fisherman level. Table 4 
summarizes the treatment effects for all model runs, significance, and results of falsification tests. Full results are in the (reviewer's) appendix (to be archived online with URL).

For all eight of the highly-susceptible species combined, we find evidence of quantity spillovers in Treatment Groups 2 and 3 that pass the falsification test. Our estimates suggest that fisherman who were members of the Sector Program (Treatment Group 2) increased landings of Mid-Atlantic species by 8,978 pounds relative to Mid-Atlantic fishermen. The estimate for those fisherman who were inactive members of as Sector (Treatment Group 3) is similar at 7,096 pounds. However, estimates of the treatment effect for the dollar value of landings was not stastically significant for any treatment definition.

Turning to individual species, the results are more varied. Atlantic mackerel is statistically significant for pounds and value in all three treatment definitions. However, only the results for dollar value and Treatment Group 1 passes a falsification test. Mackerel is caught almost exclusively with otter trawl and thus is a good substitute for groundfish species on the basis of gear, but it is a relatively weak market substitute. The passing of the falsification test for Treatment Group 1 but not for the other definitions raises questions about the treatment definitions; eliminating fishermen who have caught groundfish but who did not enroll in a sector leads to the weaker results. One possibility is that the formation of sectors caused groundfish fishermen in the common pool to intensify fishing for other species. This is not implausible given that mackerel is a high-volume and low-value fishery. It might be that fishing vessels best equipped to compete in a high-volume environment were less interested in joining a sector.

A similar mechanism could explain statistically significant Treatment Group 1 results that pass falsification tests for long-finned squid and butterfish. Like mackerel, squid is a highvolume and low-value species caught predominantly with otter trawl. Butterfish, which is also 
low-value, is caught mostly as bycatch in the squid fishery. In the sample period, there was no directed butterfish fishery. So, it is not surprising that its treatment effects track mostly with those of squid, though it is clear from Table 2 that butterfish is also caught with some other gears and thus as bycatch in other fisheries.

The results for monkfish are all negative, but only two results are statistically significant, and none pass falsification tests. In other words, there is no evidence that the Sector Program caused decreases in monkfish landings for New England fishermen relative to Mid-Atlantic fishermen.

The results for combined summer flounder and scup (the whitefish category most similar to New England groundfish) are statistically significant for pounds and dollars in Treatment Groups 1 and 2, and the Treatment Group 2 results pass falsification tests. Both of these species are strong candidates for spillover on the basis of gear and market substitutability. As such, it is not surprising that the Sector Program caused spillovers for enrolled sector members. The question is why the statistical results do not show the same for inactive sector members (Treatment Group 3). The results are positive and of similar magnitude to the Treatment Group 2 results, but lack statistical significance. One possibility is simply that inactive sector members have less profitable vessels, and it is more profitable for them to idle their vessels and allow active sector members to catch both the allocation of groundfish and some of the Mid-Atlantic spillover. We do not observe ownership structure, but it is certainly a theoretical possibility that an individual owning two vessels with different efficiencies could choose to idle one to maximize profits across the two. 
Overall, there is evidence that the Sector Program causes some spillovers into the MidAtlantic, but the evidence is not consistent across different ways of defining the treatment group, pounds versus dollars, and species groups.

\section{Discussion}

Our theoretical model predicts that positive, negative, or zero effort leakage are all possible results of the transition to the Sector Program, depending on whether various constraints bind before and after the policy change. Effort leakage, in turn, may or may not translate into changes in catches for NES and MA fishermen. The complexities of our setting echo themes in the public economics literature on multiple market distortions. When there are multiple distortions, a policy change toward the first best in one market may not influence the other market in ways one would predict from first-best reasoning (Fullerton and Metcalf 2001). Moreover, the presence of multiple distortions in a second-best world is one possible explanation for our mixed empirical results. Some fisheries appear to have positive spillovers, while others do not.

Our model does not reveal whether catch spillovers are costly to efficiency. We do not test the resulting effects on technical efficiency, and the theoretical model reveals potential outcomes that cut either way. If NES fishermen displace MA fishermen in MA fisheries, technical efficiency could increase. There would be equity considerations, especially because MA fishermen were not involved in the NES fishery policy process. On the other hand, because the Sector Program likely draws more efficient effort into NES fisheries and away from MA fisheries, NES vessels increasing participation in MA fisheries are likely less efficient and could lower the overall technical efficiency of MA fisheries. 
There are at least four possible implications of our empirical findings that the New England Sector Program caused some spillovers into Mid-Atlantic fisheries. First, potential efficiency gains from the Sector Program in New England may not reflect the full changes in efficiency; they may have been offset at least partially by efficiency losses in the Mid-Atlantic or could have contributed to increased efficiency in the Mid-Atlantic. It is important to note that we did not test this hypothesis directly, but our results are consistent with there being some unintended consequence. It could be that efficiency changes from spillovers are not large enough to warrant the costs of controlling them. We did not explore this question, which suggests a direction for future research.

Second, there may be opportunities for regions like the Mid-Atlantic to address spillovers proactively before a policy change in an adjacent region. The use of sideboard limits in Alaska essentially attempts to deal with spillovers before they occur. In several instances, the North Pacific Fishery Management Council has restricted groups of vessels that participate in one catch share-managed fishery from expanding their aggregate level of retained catch in another fishery beyond the proportion that they harvested during a qualifying period. ${ }^{8}$ Vessels without sideboard exemptions are prohibited from directed fishing in the spillover fishery once they reach their collective participation limit. The Mid-Atlantic chose not to pursue such an approach despite full knowledge of the coming sector program in New England. A reasonable question is whether the efficiency gains would have justified the cost of administering such a program in the MidAtlantic.

Third, a more radical approach would be full and complete creation of catch shares for all federally managed fisheries that do not already have catch share programs. Such programs might

\footnotetext{
${ }^{8}$ NPFMC fisheries with sideboards include: the American Fisheries Act (AFA) pollock fishery, the Crab Rationalization Program, the Central Gulf of Alaska Rockfish Program, and the "Amendment 80" Fishery (Bering Sea/Aleutian Islands non-pollock trawl catcher/processors).
} 
be a mix of individual transferable quotas, sectors, other forms of cooperatives, and territorial use rights in fisheries (TURFs), but would aim to undo residual open-access incentives in U.S. fisheries. Although changes of this sort would almost certainly be politically infeasible in the current policy climate, theoretically they would create high barriers to entry for fishing effort that might spillover from one region to another. As such, a radical policy change like this might avoid regional spillovers within the United States. The sentiment echoes that of calls to design climate policy that is all encompassing, i.e. to "think globally, act globally" (Wiener 2007). Still, broad formation of catch shares in U.S. fisheries could produce unintended consequences. Barriers to domestic commercial fishing entry would undoubtedly rise. Excess fishing capital might enter unregulated high-seas fisheries, be sold and exported to countries with less tightly controlled fisheries, or create more pressure from the domestic recreational sector by expanding the supply of charter vessels. Moreover, a policy change like this in developing countries raises questions about the impacts of fisheries reform on the poor that rely on open-access conditions as part of a livelihood strategy that blends fishing and non-fishing income (Liese, Smith, and Kramer 2007; Wilen 2013).

Lastly, spillovers may reflect complex livelihood strategies within fisheries that singlespecies management fails to acknowledge. In this sense, spillovers from a policy change may be no different from effort redirection in response to fluctuations in fish stocks or market conditions. Managers would need to know not just if spillovers were occurring, but whether they had negative efficiency consequences. Supposing that there were not efficiency losses, the management implications are very different from those described above. Managers in this case might have a stake in facilitating, not limiting, opportunities to redirect effort. Single-species TACs might be replaced by value-based IFQs (Turner 1996) or some form of portfolio 
management (Sanchirico, Smith, and Lipton 2008). These ideas, though discussed in the economics literature, have yet to emerge as practical policy proposals.

The implications discussed above are not perfectly overlapping. The possibility that spillovers are just part of a larger economic context for fishing behavior suggests that no action is necessary, but it also begs the question of why some spillover effects actually passed falsification tests. Supposing that spillovers are enough of a problem to warrant a policy action, one type of action - e.g., a complete allocation of catch shares-would negate the need for another type of action—e.g. a network of sideboards.

The notion of spillovers as livelihood raises philosophical questions about how to define the treatment and control group in our context. Already, we chose to exclude many fishermen from the control group because they had caught some sector species even if these catches were truly incidental (Table 3). Scheld and Anderson (2014), focusing on a very different question from ours, find aggregate gains of $\$ 30$ million from the Sector Program. However, they actually include gains in Mid-Atlantic fisheries in their tally (increased revenue in the Mid-Atlantic for Sector Program fishermen relative to counterfactual Mid-Atlantic revenues for Sector Program fishermen). It could be that some of what Scheld and Anderson (2014) count as gains are, in fact, transfers from the Mid-Atlantic fishermen, whereas some of what we imply are efficiency losses are, in fact, gains from better market timing that the Sector Program fishermen are able to exploit. Overall, our results are not an indictment of catch shares, but they suggest that there are possible ways to improve performance through some coordination across regions and a taking a broader view of fisheries than the single-species focus of most current management institutions. 


\section{References}

Abbott JK, Garber-Yonts B, Wilen JE. 2010. Employment and Remuneration Effects of IFQs in the Bering Sea/Aleutian Islands Crab Fisheries. Marine Resource Economics 25: 333-54.

Abbott JK, Wilen JE. 2011. Dissecting the tragedy: A spatial model of behavior in the commons. Journal of Environmental Economics and Management, 62.3: 386-401.

Asche F, Gordon DV, Jensen CL. 2007. Individual Vessel Quotas and Increased Fishing Pressure on Unregulated Species. Land Economics 83.1: 41-49.

Baylis, K., D. Fullerton, and D.H. Karney. Negative Leakage. Journal of the Association of Environmental and Resource Economists1: 51-73.

Berkes F, Hughes TP, Steneck RS, Wilson JA, Bellwood DR, et al. 2006. Ecology Globalization, roving bandits, and marine resources. Science 311: 1557-58.

Bockstael NE, Opaluch JJ. 1983. Discrete Modeling of Supply Response Under Uncertainty. Journal of Environmental Economics and Management 10: 125-37.

Bromley DW. 2009. "Abdicating responsibility: the deceits of fisheries policy." Fisheries 34.6: 280-290.

Costello C, Gaines SD, Lynham J. 2008. Can catch shares prevent fisheries collapse? Science 321: $1678-81$.

Chu C. 2009. Thirty years later: the global growth of ITQs and their influence on stock status in marine fisheries. Fish and Fisheries 10: 217-230.

Cunningham, S. 2012. A Policy Impact Analysis of New England Groundfish Sectors and Effort Redirection into Mid-Atlantic Fisheries. Masters Project, Nicholas School of the Environment, Duke University. 
Fowlie ML. 2009. Incomplete environmental regulation, imperfect competition, and emissions leakage. American Economic Journal: Economic Policy 1.2: 72-112.

Fullerton, D. and G.E. Metcalf. 2001. Environmental controls, scarcity rents, and pre-existing distortions. Journal of Public Economics 80: 249-267.

Goulder, L. H. and W.H. Parry. 2008. Instrument Choice in Environmental Policy. Review of Environmental Economics and Policy 2:152-174.

Grafton RQ, Squires D, Fox KJ. 2000. Private property and economic efficiency: A study of a common-pool resource. Journal of Law \& Economics 43: 679-713.

Hayashi F. 2000. Econometrics. Princeton, NJ: Princeton University Press.

Hicks RL, Schnier KE. 2008. Eco-labeling and dolphin avoidance: A dynamic model of tuna fishing in the Eastern Tropical Pacific. Journal of Environmental Economics and Management 56: 103-16.

Holland D, Sutinen JG. 2000. Location Choice in the New England trawl fisheries: old habits die hard. Land Economics 76: 133-49.

Holland D S, Kitts AW, Pinto Da Silva P, Wiersma J. 2013. Social Capital and the Success of Harvest Cooperatives in the New England Groundfish Fishery. Marine Resource Economics 28: 133-153.

Holland DS, Wiersma J. 2010. Free form property rights for fisheries: The decentralized design of rights-based management through groundfish "sectors" in New England. Marine Policy 34.5: 1076-1081.

Homans FR, Wilen JE. 1997. A model of regulated open access resource use. Journal of Environmental Economics and Management 32: 1-21. 
Homans, Frances R., and James E. Wilen. 2005. Markets and rent dissipation in regulated open access fisheries. Journal of Environmental Economics and Management 49: 381-404.

Hutniczak, B. 2014. Increasing pressure on unregulated species due to changes in Individual Vessel Quotas. Marine Resource Economics 29: 201-217..

Kitts AW, Pinto da Silva P, Rountree B. 2007. The evolution of collaborative management in the Northeast USA tilefish fishery. Marine Policy 31.2: 192-200.

Lian C, Singh R, Weninger Q. 2009. Fleet Restructuring, Rent Generation, and the Design of Individual Fishing Quota Programs: Empirical Evidence from the Pacific Coast Groundfish Fishery. Marine Resource Economics 24: 329-59.

Liese, C., M.D. Smith, and R.A. Kramer. 2007. Open access in a spatially delineated artisanal fishery: the case of Minahasa, Indonesia. Environment and Development Economics, 12(1), 123-143.

McCay BJ. 2004. ITQs and community: an essay on environmental governance. Agricultural and Resource Economics 33: 162-170.

Meyfroidt P, Rudel TK, Lambin EF. 2010. "Forest transitions, trade, and the global displacement of land use." Proceedings of the National Academy of Sciences 107.49: 20917-20922.

Mistiaen JA, Strand IE. 2000. Supply response under uncertainty with heterogeneous risk preferences: Location choice in longline fishing. Am. J. Agricultural Economics 82: 1184-90.

Murray BC, McCarl BA, Lee H-C. 2004. "Estimating leakage from forest carbon sequestration programs." Land Economics 80.1: 109-124.

National Oceanic and Atmospheric Administration. Fishwatch: seafood profiles. Retrieved February 15, 2012, from http://ww.fishwatch.gov/seafood_profiles/index.htm. 
Newell RG, Sanchirico JN, Kerr S. 2005. Fishing quota markets. Journal of Environmental Economics and Management 49: 437-62.

Northeast Fisheries Science Center (NEFSC). 2006. Status of fishery resources off the Northeastern United States. Retrieved February 15, 2012, from http://www.nefsc.noaa.gov/sos.

Nowlis J, Van Benthem AA. 2012. Do Property Rights Lead to Sustainable Catch Increases? Marine Resource Economics 27: 89-105.

NRC. 1999. Sharing the Fish: Toward a National Policy on Individual Fishing Quotas, National Academy Press, Washington DC.

Péreau J-C, Doyen L, Little LR, Thebaud O. 2012. "The triple bottom line: Meeting ecological, economic and social goals with individual transferable quotas." Journal of Environmental Economics and Management 63.3: 419-34.

Quaas, Martin F., and Till Requate. 2013. Sushi or Fish Fingers? Seafood Diversity, Collapsing Fish Stocks, and Multispecies Fishery Management. The Scandinavian Journal of Economics 115: 381-422.

Sanchirico JN, Smith MD, Lipton DW. 2008. An empirical approach to ecosystem-based fishery management. Ecological Economics 64.3: 586-596.

Scheld, A.M., C.M. Anderson. 2014. Market effects of catch share management: the case of New England multispecies groundfish. ICES Journal of Marine Science 71:1835-45. doi:10.1093/icesjms/fsu001

Scheld, A.M., C.M. Anderson, and H. Uchida. 2012. The Economic Effects of Catch Share Management: The Rhode Island Fluke Sector Pilot Program. Marine Resource Economics 27: 203-228. 
Seagraves R. 2012 (February 18). Personal interview.

Smith MD. 2002. Two econometric approaches for predicting the spatial behavior of renewable resource harvesters. Land Economics 78: 522-38.

Smith MD, Wilen JE. 2004. Marine Reserves with Endogenous Ports: Empirical Bioeconomics of the California Sea Urchin Fishery. Marine Resource Economics 19: 85-112.

Turner MA. 1996. Value-based ITQ's. Marine Resource Economics 11.2: 59-69.

Weninger Q. 1998. "Assessing efficiency gains from individual transferable quotas: an application to the mid-Atlantic surf clam and ocean quahog fishery." American Journal of Agricultural Economics 80.4: 750-764.

Wiener JB. 2007. Think globally, act globally: The limits of local climate policies. University of Pennsylvania Law Review 155: 1961-1979.

Wilen, J. E. 2013. The Challenges of Pro-Poor Fisheries Reform. Marine Resource Economics. 28:203-220.

Zhang J, Smith MD. 2011. Heterogeneous Response to Marine Reserve Formation: A Sorting Model approach. Environmental \& Resource Economics 49: 311-25. 
Table 1. New England Groundfish Landings in 2009

\begin{tabular}{|c|c|c|c|c|c|c|c|c|c|c|c|}
\hline Fishery & Pounds & $\begin{array}{r}\text { Value } \\
(\$)\end{array}$ & $\begin{array}{l}\text { Price } \\
(\$ / \mathrm{lb} .)\end{array}$ & $\begin{array}{l}\text { Otter Trawl } \\
\text { Pounds }\end{array}$ & $\begin{array}{l}\text { Gillnet } \\
\text { Pounds }\end{array}$ & $\begin{array}{l}\text { Other } \\
\text { Pounds }\end{array}$ & $\begin{array}{l}\text { Not Coded } \\
\text { Pounds }\end{array}$ & $\begin{array}{r}\text { Total } \\
\text { Coded } \\
\text { Pounds }\end{array}$ & $\begin{array}{r}\text { Otter Trawl } \\
\text { Coded } \\
\text { Gears }\end{array}$ & $\begin{array}{r}\text { Gillnets } \\
\text { Coded } \\
\text { Gears }\end{array}$ & $\begin{array}{l}\text { Other } \\
\text { Coded } \\
\text { Gears }\end{array}$ \\
\hline Cod & $19,442,875$ & $24,846,605$ & 1.28 & $4,094,820$ & $6,289,209$ & $1,207,489$ & $7,851,357$ & $11,591,518$ & $35 \%$ & $54 \%$ & $10 \%$ \\
\hline Haddock & $12,233,976$ & $12,945,104$ & 1.06 & $4,231,480$ & 251,247 & 378,197 & $7,373,052$ & $4,860,924$ & $87 \%$ & $5 \%$ & $8 \%$ \\
\hline Plaice & $3,040,214$ & $3,853,125$ & 1.27 & $1,482,549$ & 125,134 & 19,755 & $1,412,776$ & $1,627,438$ & $91 \%$ & $8 \%$ & $1 \%$ \\
\hline Winter Flounder & $4,703,928$ & $7,824,370$ & 1.66 & $1,260,068$ & 133,372 & 342,657 & $2,967,831$ & $1,736,097$ & $73 \%$ & $8 \%$ & $20 \%$ \\
\hline Yellowtail Flounder & $3,435,682$ & $4,606,270$ & 1.34 & $1,158,562$ & 144,443 & 114,293 & $2,018,384$ & $1,417,298$ & $82 \%$ & $10 \%$ & $8 \%$ \\
\hline Pollock & $16,020,335$ & $9,762,477$ & 0.61 & $5,472,406$ & $5,604,208$ & 45,371 & $4,898,350$ & $11,121,985$ & $49 \%$ & $50 \%$ & $0 \%$ \\
\hline Hake (Silver, Red, and White) & $15,466,145$ & $9,055,847$ & 0.59 & $6,000,691$ & 855,854 & 41,427 & $8,568,173$ & $6,897,972$ & $87 \%$ & $12 \%$ & $1 \%$ \\
\hline Redfish & $3,097,815$ & $1,501,659$ & 0.48 & 965,860 & 156,294 & 494 & $1,975,167$ & $1,122,648$ & $86 \%$ & $14 \%$ & $0 \%$ \\
\hline Total & $77,440,970$ & $74,395,457$ & 0.96 & $24,666,436$ & $13,559,761$ & $2,149,683$ & $37,065,090$ & $40,375,880$ & $61 \%$ & $34 \%$ & $5 \%$ \\
\hline
\end{tabular}

Note:

Data from National Marine Fisheries Service Commercial Fisheries Statistics, http://www.st.nmfs.noaa.gov/commercial-fisheries/index 
Table 2. Mid-Atlantic Fisheries Landings in 2009

\begin{tabular}{|c|c|c|c|c|c|c|c|c|c|c|c|}
\hline Fishery & Pounds & $\begin{array}{r}\text { Value } \\
\text { (\$) }\end{array}$ & $\begin{array}{l}\text { Price } \\
(\$ / \mathrm{lb} .) \\
\end{array}$ & $\begin{array}{l}\text { Otter } \\
\text { Trawl } \\
\text { Pounds }\end{array}$ & $\begin{array}{l}\text { Gillnet } \\
\text { Pounds }\end{array}$ & $\begin{array}{l}\text { Other } \\
\text { Pounds }\end{array}$ & $\begin{array}{r}\text { Not Coded } \\
\text { Pounds }\end{array}$ & $\begin{array}{r}\text { Total Coded } \\
\text { Pounds }\end{array}$ & $\begin{array}{r}\text { Otter Trawl } \\
\text { Coded } \\
\text { Gears } \\
\end{array}$ & $\begin{array}{r}\text { Gillnets } \\
\text { Coded } \\
\text { Gears }\end{array}$ & $\begin{array}{r}\text { Other } \\
\text { Coded } \\
\text { Gears }\end{array}$ \\
\hline \multicolumn{12}{|l|}{ Whitefish } \\
\hline Summer Flounder & $10,430,771$ & $21,581,799$ & 2.07 & $6,286,293$ & 114,129 & 937,118 & $3,093,231$ & $7,337,540$ & $86 \%$ & $2 \%$ & $13 \%$ \\
\hline Scup & $7,870,465$ & $6,075,339$ & 0.77 & $2,117,178$ & 0 & $1,227,346$ & $4,525,941$ & $3,344,524$ & $63 \%$ & $0 \%$ & $37 \%$ \\
\hline Black Sea Bass & $1,614,382$ & $4,404,751$ & 2.73 & 325,145 & 6,556 & 853,748 & 428,933 & $1,185,449$ & $27 \%$ & $1 \%$ & $72 \%$ \\
\hline Golden Tilefish & $1,987,317$ & $4,457,145$ & 2.24 & 4,663 & 0 & 657,942 & $1,324,712$ & 662,605 & $1 \%$ & $0 \%$ & $99 \%$ \\
\hline \multicolumn{12}{|l|}{ Other Seafood } \\
\hline Monkfish & $18,873,932$ & $19,172,676$ & 1.02 & $3,364,083$ & $7,455,965$ & $1,501,492$ & $6,552,392$ & $12,321,540$ & $27 \%$ & $61 \%$ & $12 \%$ \\
\hline Atlantic Mackerel & $29,975,463$ & $6,375,267$ & 0.21 & $26,830,346$ & 6 & 583,676 & $2,561,435$ & $27,414,028$ & $98 \%$ & $0 \%$ & $2 \%$ \\
\hline Butterfish & 990,073 & 632,757 & 0.64 & 378,773 & 49,774 & 50,464 & 511,062 & 479,011 & $79 \%$ & $10 \%$ & $11 \%$ \\
\hline Longfin Squid & $19,847,227$ & $18,106,368$ & 0.91 & $7,834,463$ & 0 & 258,022 & $11,754,742$ & $8,092,485$ & $97 \%$ & $0 \%$ & $3 \%$ \\
\hline Bluefish & $6,441,298$ & $2,533,036$ & 0.39 & 404,078 & $3,863,855$ & 507,583 & $1,665,782$ & $4,775,516$ & $8 \%$ & $81 \%$ & $11 \%$ \\
\hline Surfclam & $45,986,208$ & $30,928,637$ & 0.67 & 0 & 0 & $40,880,938$ & $5,105,270$ & $40,880,938$ & $0 \%$ & $0 \%$ & $100 \%$ \\
\hline Ocean Quahog & $12,969,390$ & $8,748,296$ & 0.67 & 0 & 0 & $12,969,390$ & 0 & $12,969,390$ & $0 \%$ & $0 \%$ & $100 \%$ \\
\hline Spiny Dogfish & $1,300,711$ & 361,273 & 0.28 & 190,804 & 335,794 & 245,044 & 529,069 & 771,642 & $25 \%$ & $44 \%$ & $32 \%$ \\
\hline Total & $158,287,237$ & $123,377,344$ & 0.78 & $47,735,826$ & $11,826,079$ & $60,672,763$ & $38,052,569$ & $120,234,668$ & $40 \%$ & $10 \%$ & $50 \%$ \\
\hline
\end{tabular}

Notes:

Data from National Marine Fisheries Service Commercial Fisheries Statistics, http://www.st.nmfs.noaa.gov/commercialfisheries/index

Shortfin squid is also managed by the Mid-Atlantic Council but does not appear in the aggregate landings-by-gear data for 2009. 
Table 3. Number of Individual Fishermen Included in Each Species Aggregation Analysis

\begin{tabular}{|c|c|c|c|c|c|c|}
\hline Species & $\begin{array}{l}\text { Number } \\
\text { of } \\
\text { Species }\end{array}$ & $\begin{array}{l}\text { Total } \\
\text { Individual } \\
\text { Fishermen }\end{array}$ & Control & Treat 1 & Treat 2 & Treat 3 \\
\hline Complete Mid-Atlantic Species Roster & 13 & 2559 & 1211 & 1348 & 523 & 165 \\
\hline High-Susceptibility Effort-Receiving Species & 8 & 2380 & 1058 & 1322 & 484 & 136 \\
\hline Long-finned Squid & 1 & 586 & 128 & 458 & 168 & 49 \\
\hline Atlantic Mackerel & 1 & 555 & 81 & 474 & 215 & 48 \\
\hline Butterfish & 1 & 519 & 103 & 416 & 142 & 40 \\
\hline Monkfish & 1 & 1679 & 588 & 1091 & 466 & 130 \\
\hline Scup/Summer Flounder Combined & 2 & 1451 & 642 & 809 & 247 & 68 \\
\hline
\end{tabular}


Table 4. Treatment Effect Model Results

\begin{tabular}{|c|c|c|c|c|c|c|}
\hline \multirow[b]{2}{*}{ Species } & \multicolumn{5}{|c|}{ Treatment Definition } & \\
\hline & Group 1 & & Group 2 & & Group 3 & \\
\hline \multicolumn{7}{|l|}{ Pounds } \\
\hline \multicolumn{7}{|l|}{ All High-Susceptibility } \\
\hline Species & 123 & & 8,978 & $*,+$ & 7,096 & $*,+$ \\
\hline Atlantic Mackerel & 61,241 & $*$ & 74,340 & $*$ & 95,229 & $*$ \\
\hline Butterfish & 482 & $*,+$ & 839 & $*,+$ & 313 & \\
\hline Longfin Squid & 2,336 & $*,+$ & (902) & & $(2,176)$ & \\
\hline Monkfish & (531) & $*$ & (979) & $*$ & (1224) & \\
\hline Summer Founder + Scup & 917 & $*$ & 3,133 & $*,+$ & 2,339 & \\
\hline \multicolumn{7}{|l|}{$\underline{\text { Value }}$} \\
\hline \multicolumn{7}{|l|}{ All High-Susceptibility } \\
\hline Species & $\$ 246$ & & $\$ 1,180$ & & $\$(1,493)$ & \\
\hline Atlantic Mackerel & $\$ 8,720$ & $*,+$ & $\$ 11,589$ & $*$ & $\$ 14,155$ & $*$ \\
\hline Butterfish & $\$ \quad 271$ & $*,+$ & 418 & $*,+$ & 176 & \\
\hline Longfin Squid & $\$ 4,110$ & $*,+$ & $\$ 4,393$ & & 350 & \\
\hline Monkfish & $\$(641)$ & $*$ & $\$(1,558)$ & $*$ & $\$(2,752)$ & \\
\hline Summer Founder + Scup & $\$ 949$ & $*$ & $\$ 2,199$ & $*,+$ & $\$ 1,278$ & \\
\hline Notes: & & & & & & \\
\hline
\end{tabular}




\section{Reviewer's Appendix - All treatment effect results (all 36 model runs)}

Results in gray indicate that the estimates are statistically significant at the $5 \%$ level and pass the falsification test.

\begin{tabular}{|c|c|c|c|c|c|c|}
\hline Species & All & All & All & All & All & All \\
\hline Treatment Definition & 1 & 1 & 2 & 2 & 3 & 3 \\
\hline Dependent Variable & Pounds & Pounds & Pounds & Pounds & Pounds & Pounds \\
\hline Result or Falsification Test & Results & Falsification & Results & Falsification & Results & Falsification \\
\hline Treatment Estimate & 122.6 & -4867.9 & 8978.3 & 3493.1 & 7096.1 & 531.3 \\
\hline \multirow[t]{2}{*}{ Treatment Standard Error } & 2902.1 & 3427.9 & 2513.6 & 3512.0 & 3335.4 & 3570.2 \\
\hline & Atlantic & Atlantic & Atlantic & Atlantic & Atlantic & Atlantic \\
\hline Species & Mackerel & Mackerel & Mackerel & Mackerel & Mackerel & Mackerel \\
\hline Treatment Definition & 1 & 1 & 2 & 2 & 3 & 3 \\
\hline Dependent Variable & Pounds & Pounds & Pounds & Pounds & Pounds & Pounds \\
\hline Result or Falsification Test & Results & Falsification & Results & Falsification & Results & Falsification \\
\hline Treatment Estimate & 61241 & 41375.9 & 74340.4 & 58113.6 & 95228.6 & 57838.2 \\
\hline Treatment Standard Error & 18854.4 & 20455.7 & 25074.1 & 19104.0 & 32308.6 & 19173.7 \\
\hline Species & Butterfish & Butterfish & Butterfish & Butterfish & Butterfish & Butterfish \\
\hline Treatment Definition & 1 & 1 & 2 & 2 & 3 & 3 \\
\hline Dependent Variable & Pounds & Pounds & Pounds & Pounds & Pounds & Pounds \\
\hline Result or Falsification Test & Results & Falsification & Results & Falsification & Results & Falsification \\
\hline Treatment Estimate & 481.9 & -143.6 & 839.2 & 12.1 & 313.3 & -619.6 \\
\hline Treatment Standard Error & 139.9 & 143.3 & 247.5 & 258.9 & 453.3 & 778.4 \\
\hline
\end{tabular}




\begin{tabular}{|c|c|c|c|c|c|c|}
\hline Species & Loligo & Loligo & Loligo & Loligo & Loligo & Loligo \\
\hline Treatment Definition & 1 & 1 & 2 & 2 & 3 & 3 \\
\hline Dependent Variable & Pounds & Pounds & Pounds & Pounds & Pounds & Pounds \\
\hline Result or Falsification Test & Results & Falsification & Results & Falsification & Results & Falsification \\
\hline Treatment Estimate & 2335.7 & -2530.8 & -902.1 & -1470.7 & -2175.7 & 125.9 \\
\hline Treatment Standard Error & 1133.4 & 2590.0 & 2050.9 & 2990.6 & 3397.9 & 4222.3 \\
\hline Species & Monkfish & Monkfish & Monkfish & Monkfish & Monkfish & Monkfish \\
\hline Treatment Definition & 1 & 1 & 2 & 2 & 3 & 3 \\
\hline Dependent Variable & Pounds & Pounds & Pounds & Pounds & Pounds & Pounds \\
\hline Result or Falsification Test & Results & Falsification & Results & Falsification & Results & Falsification \\
\hline Treatment Estimate & -531 & -723.0 & -979.2 & -1246.9 & -1224.1 & -1620.1 \\
\hline Treatment Standard Error & 149 & 189.7 & 210.2 & 280.1 & 408.2 & 579.5 \\
\hline Species & $\begin{array}{l}\text { Summer } \\
\text { Flounder } \\
\text { and Scup }\end{array}$ & $\begin{array}{l}\text { Summer } \\
\text { Flounder } \\
\text { and Scup }\end{array}$ & $\begin{array}{l}\text { Summer } \\
\text { Flounder } \\
\text { and Scup }\end{array}$ & $\begin{array}{l}\text { Summer } \\
\text { Flounder } \\
\text { and Scup }\end{array}$ & $\begin{array}{l}\text { Summer } \\
\text { Flounder } \\
\text { and Scup }\end{array}$ & $\begin{array}{l}\text { Summer } \\
\text { Flounder } \\
\text { and Scup }\end{array}$ \\
\hline Treatment Definition & 1 & 1 & 2 & 2 & 3 & 3 \\
\hline Dependent Variable & Pounds & Pounds & Pounds & Pounds & Pounds & Pounds \\
\hline Result or Falsification Test & Results & Falsification & Results & Falsification & Results & Falsification \\
\hline Treatment Estimate & 916.8 & -671.0 & 3132.5 & 207.9 & 2339.1 & 709.5 \\
\hline Treatment Standard Error & 304.3 & 349.4 & 776.1 & 673.7 & 1379.4 & 1620.9 \\
\hline
\end{tabular}




\begin{tabular}{|c|c|c|c|c|c|c|}
\hline Species & All & All & All & All & All & All \\
\hline Treatment Definition & 1 & 1 & 2 & 2 & 3 & 3 \\
\hline Dependent Variable & Value & Value & Value & Value & Value & Value \\
\hline Result or Falsification Test & Results & Falsification & Results & Falsification & Results & Falsification \\
\hline Treatment Estimate & 245.6 & -2971.5 & 1179.6 & -946.9 & -1492.5 & -2665.0 \\
\hline \multirow[t]{2}{*}{ Treatment Standard Error } & 782.0 & 782.0 & 1317.6 & 1168.4 & 1976.0 & 2394.0 \\
\hline & Atlantic & Atlantic & Atlantic & Atlantic & Atlantic & Atlantic \\
\hline Species & Mackerel & Mackerel & Mackerel & Mackerel & Mackerel & Mackerel \\
\hline Treatment Definition & 1 & 1 & 2 & 2 & 3 & 3 \\
\hline Dependent Variable & Value & Value & Value & Value & Value & Value \\
\hline Result or Falsification Test & Results & Falsification & Results & Falsification & Results & Falsification \\
\hline Treatment Estimate & 8720.4 & 3242.7 & 11589.4 & 5133.9 & 14154.8 & 5070.3 \\
\hline Treatment Standard Error & 3389.2 & 2712.5 & 4265.4 & 2554.4 & 5216.7 & 2567.0 \\
\hline Species & Butterfish & Butterfish & Butterfish & Butterfish & Butterfish & Butterfish \\
\hline Treatment Definition & 1 & 1 & 2 & 2 & 3 & 3 \\
\hline Dependent Variable & Value & Value & Value & Value & Value & Value \\
\hline Result or Falsification Test & Results & alsification & Results & Falsification & Results & Falsification \\
\hline Treatment Estimate & 271.4 & -79.6 & 417.7 & 114.3 & 176.5 & -221.3 \\
\hline Treatment Standard Error & 86.9 & 90.6 & 132.9 & 136.2 & 237.9 & 349.5 \\
\hline Species & Loligo & Loligo & Loligo & Loligo & Loligo & Loligo \\
\hline Treatment Definition & 1 & 1 & 2 & 2 & 3 & 3 \\
\hline Dependent Variable & Value & Value & Value & Value & Value & Value \\
\hline Result or Falsification Test & Results & Falsification & Results & Falsification & Results & Falsification \\
\hline Treatment Estimate & 4109.7 & -630.2 & 4393.4 & 1510.0 & 350.1 & 1349.9 \\
\hline Treatment Standard Error & 1230.2 & 1970.1 & 2298.8 & 2334.1 & 3871.1 & 3565.8 \\
\hline Species & Monkfish & Monkfish & Monkfish & Monkfish & Monkfish & Monkfish \\
\hline
\end{tabular}




\begin{tabular}{|c|c|c|c|c|c|c|}
\hline $\begin{array}{l}\text { Treatment Definition } \\
\text { Dependent Variable } \\
\text { Result or Falsification Test }\end{array}$ & $\begin{array}{c}1 \\
\text { Value } \\
\text { Results }\end{array}$ & $\begin{array}{c}1 \\
\text { Value } \\
\text { Falsification }\end{array}$ & $\begin{array}{c}2 \\
\text { Value } \\
\text { Results }\end{array}$ & $\begin{array}{c}2 \\
\text { Value } \\
\text { Falsification }\end{array}$ & $\begin{array}{c}3 \\
\text { Value } \\
\text { Results }\end{array}$ & $\begin{array}{c}3 \\
\text { Value } \\
\text { Falsification }\end{array}$ \\
\hline Treatment Estimate & -641.0 & -1197.1 & -1558.0 & -1815.9 & -2752.1 & -2494.8 \\
\hline Treatment Standard Error & 262.6 & 303.9 & 426.3 & 484.5 & 859.3 & 950.9 \\
\hline Species & $\begin{array}{l}\text { Summer } \\
\text { Flounder } \\
\text { and Scup }\end{array}$ & $\begin{array}{l}\text { Summer } \\
\text { Flounder } \\
\text { and Scup }\end{array}$ & $\begin{array}{l}\text { Summer } \\
\text { Flounder } \\
\text { and Scup }\end{array}$ & $\begin{array}{l}\text { Summer } \\
\text { Flounder } \\
\text { and Scup }\end{array}$ & $\begin{array}{l}\text { Summer } \\
\text { Flounder } \\
\text { and Scup }\end{array}$ & $\begin{array}{l}\text { Summer } \\
\text { Flounder } \\
\text { and Scup }\end{array}$ \\
\hline Treatment Definition & 1 & 1 & 2 & 2 & 3 & 3 \\
\hline Dependent Variable & Value & Value & Value & Value & Value & Value \\
\hline Result or Falsification Test & Results & Falsification & Results & Falsification & Results & Falsification \\
\hline Treatment Estimate & 949.2 & -1245.1 & 2199.0 & 688.1 & 1277.5 & -22.8 \\
\hline Treatment Standard Error & 396.5 & 513.6 & 858.7 & 888.1 & 1605.4 & 2140.1 \\
\hline
\end{tabular}

